NBER WORKING PAPER SERIES

\title{
CURRENT AND FUTURE PREVALENCE OF OBESITY AND SEVERE OBESITY IN THE UNITED STATES
}

\author{
Christopher J. Ruhm
}

Working Paper 13181

http://www.nber.org/papers/w13181

\author{
NATIONAL BUREAU OF ECONOMIC RESEARCH \\ 1050 Massachusetts Avenue \\ Cambridge, MA 02138 \\ June 2007
}

I thank Whitney Garner for outstanding research assistance. The views expressed herein are those of the author(s) and do not necessarily reflect the views of the National Bureau of Economic Research.

(C) 2007 by Christopher J. Ruhm. All rights reserved. Short sections of text, not to exceed two paragraphs, may be quoted without explicit permission provided that full credit, including $\odot$ notice, is given to the source. 
Current and Future Prevalence of Obesity and Severe Obesity in the United States

Christopher J. Ruhm

NBER Working Paper No. 13181

June 2007

JEL No. I1,I12

\begin{abstract}
$\underline{\text { ABSTRACT }}$
The prevalence of obesity has increased rapidly since the mid-1970s, following a period of relative stability. This study examines past patterns and projects future prevalence rates of obesity and severe obesity among US adults through 2020. Trends in body mass index (BMI), overweight (BMI 25), obesity (BMI 30), class 2 obesity (BMI 35), class 3 obesity (BMI 40) and class 4 obesity (BMI 45) of 20-74 year olds are obtained using data from the first National Health Examination Survey and the Nutrition Health and Nutrition Examination Surveys. Quantile regression methods are then used to forecast future prevalence rates through 2020. By that year, $77.6 \%$ of men are predicted to be overweight and $40.2 \%$ obese, with class 2,3 and 4 obesity prevalence rates projected at $16.4 \%, 6.3 \%$ and $3.1 \%$. The corresponding forecasts for women are $71.1 \%, 43.3 \%, 25.3 \%, 12.8 \%$ and $5.8 \%$. The large growth predicted for severe obesity represents a major public health challenge, given the accompanying high medical expenditures and elevated risk of mortality and morbidity. Combating severe obesity is likely to require strategies targeting the particularly large weight gains of the heaviest individuals.

Christopher J. Ruhm

Department of Economics

Bryan School, UNCG

P.O. Box 26165

Greensboro, NC 27402-6165

and NBER

chrisruhm@uncg.edu
\end{abstract}




\section{Current and future prevalence of obesity and severe obesity in the United States}

Americans are gaining weight. The average adult added 9 to 12 pounds during the 1990s (Freeman et al., 2002). Persons with a body mass index (BMI) of $25 \mathrm{~kg} / \mathrm{m}^{2}$ or more are classified as overweight (World Health Organization, 1997; National Heart, Lung and Blood Institute, 1998). Using this criterion, almost two-thirds of Americans 20 and older weighed too much in 1999-2000, compared to 46 percent in 1976-80 (Flegal et al., 1998, 2002). The prevalence of overweight and obesity is particularly high in the US but is growing rapidly throughout much of the world (World Health Organization, 1997; International Obesity Task Force, 2005).

The rise in excess weight in the US has been widely documented (Flegal et al., 2002; Mokdad et al., 2001; Hedley et al., 2004). However, because the BMI distribution has both shifted to the right and become increasingly skewed (Flegal and Troiano, 2000), severe obesity has increased especially quickly. Based on self-reported data, the 10th percentile of the adult BMI distribution rose $0.6 \mathrm{~kg} / \mathrm{m}^{2}$ between $1990-91$ and 2000 , compared to $1.2 \mathrm{~kg} / \mathrm{m}^{2}$ at the median and $3.2 \mathrm{~kg} / \mathrm{m}^{2}$ at the 95th percentile (Freedman et al., 2002). Examination data reveal that median adult BMI rose 9.5 percent between 1976-80 and 1999-2000, versus 15.2 percent at the 95th percentile (Anderson et al., 2003). The prevalence of obesity (BMI $\geq 30$ ) doubled between 1986 and 2000, based on self-reported data, while class 3 obesity (BMI $\geq 40$ ) quadrupled and BMI $\geq 50$ quintupled (Sturm, 2003).

The growth of obesity, particularly in its most extreme forms, is a major current public health issue and is likely to become even more problematic in the future. Compared to normal weight or overweight but non-obese individuals, the severely obese have substantially elevated 
mortality (Allison et al., 1999; Calle et al., 1999; Engeland et al., 2003; Fontaine et al., 2003;

Peeters et al., 2003; Flegal et al., 2005) and much higher rates of diabetes, high blood pressure, asthma and other diseases (Must et al., 1999; Mokdad et al., 2001; Okoro et al, 2004). Extreme obesity raises medical expenditures, stresses the health care system and results in productivity losses due to disability, illness and premature mortality (Quesenberry, 1998; Thompson et al., 2001; Finkelstein et al., 2003; Andreyeva et al., 2004). Olshansky et al., (2005) raise concern that growing obesity may limit or even reverse historical gains in life expectancy. Since their analysis did not account for the effects of excess weight beyond a BMI of $35 \mathrm{~kg} / \mathrm{m}^{2}$, it may understate the decline in lifespan associated with the rapid increases in severe adiposity.

This study begins by detailing trends in adult body weight since the 1960s. Compared to earlier research, it supplies unusually detailed information on changes over the entire BMI distribution, which is important for the second stage of analysis - forecasting the future prevalence of overweight, obesity and severe obesity. Predictions, through 2020, are obtained assuming a continuation of recent trends and using quantile regression techniques that provide a flexible method of allowing increases in BMI to differ across the distribution (e.g. to be larger at the $90^{\text {th }}$ than the $50^{\text {th }}$ percentile) in ways that closely align with observed patterns. The investigation next decomposes obesity trends into the portions due to population-wide increases in BMI and those resulting from particularly large growth among the heaviest individuals. For ease of exposition, these will often be referred to as "general” versus “concentrated” weight gains.

The study yields three major findings. First, it confirms previous evidence that rapid increases in overweight and obesity date from the middle 1970s and followed a period of relative stability. Although this partially reflects shifts in the entire BMI distribution, disproportionately 
large growth occurred at the highest BMI levels. Second, a continuation of these trends implies that the prevalence of all forms of excess weight will rise in the future, but with particularly rapid increases in severe and extreme obesity. ${ }^{1}$ Third, future growth in overweight and mild forms of obesity is predicted to largely result from overall shifts in the BMI distribution and might therefore be effectively addressed by efforts achieving modest but widely distributed reductions in weight. By contrast, previous and expected future increases in severe obesity are dominated by the particularly large weight growth in the right tail of the distribution. Reducing these prevalence rates is therefore likely to require new medical and behavioral interventions targeted at extremely obese adults and high risk youths.

\section{Data and Outcomes}

Baseline information was obtained from the first National Health Examination Survey (NHES 1, 1960-1962), the first, second and third National Health and Nutrition Examination Surveys (NHANES 1, 1971-1974; NHANES 2, 1976-1980; NHANES 3, 1988-1994), and from the first six years (1999-2004) of the most recent NHANES survey (hereafter referred to as NHANES 99), which is continuously conducted and with data publicly released at two year intervals. $^{2}$ Each of these is a cross-sectional nationally representative survey conducted by the National Center for Health Statistics, Centers for Disease Control and Prevention. They were designed to provide prevalence estimates for selected diseases and risk factors, monitor trends in

\footnotetext{
${ }^{1}$ Of course, recent trends may not continue, in part because of public health campaigns and policy initiatives aimed at slowing or reversing future increases in body weight. The success of these efforts remains uncertain, however, and it is useful to understand the patterns predicted by current trends.

2 Additional information on these data sets is available from National Center for Health Statistics $(1965,1994)$; Miller (1973); McDowell et al. (1981), and at the website: http://www.cdc.gov/nchs/nhanes.htm.
} 
risky behaviors and environmental exposures, and to study the relationship between diet, nutrition, and health.

The NHES/NHANES data have several features that are particularly useful for this project. Most importantly, almost all respondents complete health and laboratory examinations that include clinical measurements of height and weight obtained using standardized procedures and equipment. ${ }^{3}$ Such clinical data are helpful because self-reports of height and weight contain errors that generally lead to an underestimate of BMI, with most evidence suggesting a bigger downwards bias for heavier individuals. ${ }^{4}$ Sample sizes are also reasonably large - although bigger samples would be desirable when measuring low-prevalence conditions such as severe obesity - and minorities and senior citizens are oversampled. Finally, sufficient information is provided on the geographic location and sampling strategy to permit standard errors to be corrected for complex survey design.

Analysis is restricted to 20-74 year olds because different weight classification criteria are used for persons under 20 and individuals older than 74 are excluded from NHANES 2. Pregnant women are retained in the primary analysis sample because larger than anticipated differences in reported pregnancy rates across NHANES surveys raised the possibility of classification errors. Sensitivity analysis conducted after omitting pregnant women yielded virtually identical estimates to those presented below.

BMI is calculated as weight in kilograms divided by height in meters squared. Following national and international standards (World Health Organization, 1997; National Heart, Lung

\footnotetext{
${ }^{3}$ For the NHES, two pounds were subtracted from measured weight, because the examinee was partially dressed (unlike the other surveys where individuals wore only underwear) and the remaining clothing was estimated to weigh approximately two pounds (National Center for Health Statistics, 1981).

${ }^{4}$ Specifically, there is a tendency over-report height and understate weight (Strauss, 1999; Goodman et al., 2000; Kuczmarski et al., 2001). A number of (not entirely satisfactory) regression-based procedures have been proposed for correcting the self-report errors.
} 
and Blood Institute, 1998), overweight is defined as BMI $\geq 25$, obesity as BMI $\geq 30$, class 2 obesity as BMI $\geq 35$ and class 3 obesity as $\mathrm{BMI} \geq 40 .{ }^{5}$ No standards have been established for obesity beyond class 3 . This analysis categorizes “class 4 ” obesity as BMI $\geq 45$, to illustrate growth of a more extreme form of excess weight.

\section{Empirical Methods}

Trends in BMI and the prevalence of overweight and alternative classes of obesity were ascertained for all 20-74 year olds and for subsamples stratified by sex. Total changes and annual growth rates were calculated for the period from NHES 1 (1960-1962) to NHANES 2 (1976-1980) and from NHANES 2 to NHANES 99 (1999-2004), as well as for some subperiods. Annual percent changes were based on years elapsed between the midpoints of the specified surveys (i.e. a 17-year time difference between 1960-1962 and 1976-1980; a 13-year difference between 1976-1980 and 1988-1994; and a 10.5-year difference between 1988-1994 and 19992004). All statistical and econometric analysis was conducted using the STATA statistical software (StataCorp, 2005). Sampling weights were incorporated to allow for unequal selection probabilities and standard errors were computed using Taylor series linearization methods to account for complex survey design.

Future prevalence rates were projected as the fraction of the population, in the specified year, predicted to have BMI at or above the threshold level (e.g. $\geq 30 \mathrm{~kg} / \mathrm{m}^{2}$ for obesity). Traditional regression methods are useful for estimating relationships between covariates and

\footnotetext{
${ }^{5} \mathrm{BMI}$ is the favored method of assessing excess weight since it is simple, rapid, and inexpensive to calculate. However, it is less accurate than laboratory measures of body composition because it does not account for variations in muscle mass or the distribution of body fat (e.g. intra-abdominal versus overall adiposity). Some researchers prefer alternative anthropometric measures such as waist circumference (Sönmez et al., 2003), waist-hip ratio (Dalton et al., 2003), or waist-height ratio (Cox and Whichelow, 1996). Cawley and Burkhauser (2006) have recently recommended the use of Bioelectrical Impedance Analysis (BIA).
} 
mean values of the dependent variable but, without strong parametric assumptions, will not accurately indicate changes at other points in the distribution. Such restrictions are unlikely to be justified since, as shown below, BMI increased more over time (in both absolute and percentage terms) at high than low values.

As an alternative, future outcomes were forecasted using a series of quantile regressions that allowed BMI growth trends to vary across the distribution. ${ }^{6}$ The projections were based on time trends using data from NHANES 2, 3 and 99, covering the period 1976-1980 to 1999-2004. Data from NHES 1 and NHANES 1 were excluded because the BMI distribution changed little during these periods. The dependent variable in the quantile regressions was body mass index. Covariates included dummy variables for race/ethnicity (non-Hispanic Black, Hispanic, other nonwhite) and age (25-29, 30-34, 35-39, 40-44, 45-49, 50-54, 55-59, 60-64, 65-69 and 70-74 years old), as well as linear time trends showing years elapsed since $1975{ }^{7}$

Quantile regressions were estimated for each of the $1^{\text {st }}$ through $99^{\text {th }}$ BMI percentiles (a total of 99 estimates). Projected BMI, at the specified percentile, was obtained by setting the time trend to its value in the forecast year of interest (2001, 2010 or 2020), with other explanatory variables evaluated at the NHANES 99 averages. ${ }^{8}$ The forecasts were therefore based on the race/ethnicity and age characteristics of the 1999-2004 population. ${ }^{9}$

\footnotetext{
${ }^{6}$ Quantile regression minimizes the weighted sum of the absolute deviations of the error term, unlike standard regression that minimizes the sum of the squared residuals (Manning et al., 1995; Koenker and Hollack, 2001). At quantile q, the weights q and (1-q) are applied to positive and negative residuals. In the special case of median regression, q and (1-q) are both 0.5 , implying that estimates minimize the unweighted sum of the absolute residuals.

7 The survey year was not specified in the public-use versions of NHANES 3 and 99 but the data sets do indicate whether measurements occurred in 1988-1991, 1991-1994, 1999-2000, 2001-2002 or 2003-2004. The year was set to the midpoint of the range in these cases (1989.5, 1992.5, 1999.5, 2001.5 and 2003.5).

${ }^{8}$ Sampling weights were incorporated throughout.

${ }^{9}$ The same procedure, but with the explanatory variables set to the NHANES 2 means, was used when predicting 2001 values based on 1976-1980 population characteristics.
} 
Overweight and obesity prevalence rates were calculated by linear interpolation between adjacent percentiles where expected BMI spanned the threshold. For instance, if BMI was predicted to be $34.75 \mathrm{~kg} / \mathrm{m}^{2}$ at the $87^{\text {th }}$ percentile and $35.25 \mathrm{~kg} / \mathrm{m}^{2}$ at the $88^{\text {th }}$ percentile, the estimated prevalence of class 2 obesity at 12.5 percent (since $35.0 \mathrm{~kg} / \mathrm{m}^{2}$ is half way between the two estimates). These interpolations will be quite accurate when the difference in BMI is across adjacent percentiles is small but less so in tails of the distribution, where the changes are often quite large. Therefore, forecasts of class 3 or class 4 obesity involved the additional step of estimating quantile regressions for each 0.1 percentile within the BMI percentile spanning the threshold value and then using linear interpolation for the adjacent 0.1 percentiles above and below it. To illustrate, if predicted BMI at the $95^{\text {th }}$ and $96^{\text {th }}$ percentile was $44.05 \mathrm{~kg} / \mathrm{m}^{2}$ and $45.83 \mathrm{~kg} / \mathrm{m}^{2}$, estimates would be obtained for the $95.1^{\text {st }}$ through $95.9^{\text {th }}$ percentiles. If these indicated that BMI was $44.95 \mathrm{~kg} / \mathrm{m}^{2}$ and $45.05 \mathrm{~kg} / \mathrm{m}^{2}$ at the $95.4^{\text {th }}$ and $95.5^{\text {th }}$ percentile, the prevalence of class 4 obesity was forecasted to be 4.55 percent.

Prevalence rates were estimated separately for males and females. Rates for the combined (male and female) sample were calculated as a weighted average of the sex-specific prevalence rates, with weights corresponding to NHANES 99 population shares. Median BMI was forecasted as the predicted value at the 50th percentile in the specified year, using the methods just described, except that the value for the combined sample of men and women was obtained from a single (full sample) median regression.

Ninety-five percent confidence intervals were constructed in two steps. First, prevalence rates at each BMI percentile were forecasted (for the specified year) after subtracting or adding 1.96 times the associated standard error to the trend regression coefficient. Next, upper and 
lower bounds on the 95 percent confidence interval were obtained using these forecasts and the linear interpolation procedures described above.

Secular increases in obesity may reflect a combination of a general rise in body weight and disproportionate growth at the top of the distribution. The contribution of population-wide growth is BMI was obtained by the following procedure: 1) quantile regression was used to estimate annual growth in sex-specific median BMI; 2) the increase in median BMI predicted to occur between the baseline and forecast periods was then calculated and added to the BMI of each respondent in the baseline NHANES survey; 3) median BMI and overweight/obesity prevalence rates were computed using the transformed data and differences between these and corresponding statistics from the untransformed data were attributed to general growth in body weight. To illustrate, assume that median BMI was predicted (in step one) to increase by 0.110 $\mathrm{kg} / \mathrm{m}^{2}$ per year. This implies projected growth of $2.035 \mathrm{~kg} / \mathrm{m}^{2}\left(18.5 \times 0.110 \mathrm{~kg} / \mathrm{m}^{2}\right)$ between 2001.5 - midpoint of NHANES 99 - and 2020. If adding this amount to the BMI of each NHANES 99 sample member raises obesity prevalence from 30 to 35 percent, then a 5percentage point increase is attributed to general weight gains. Assuming that the obesity rate was forecasted to be 38 percent in 2020 (using the quantile regressions), the residual 3-point rise, corresponding to 37.5 percent (3 out of 8 percentage points) of the total increase, would be attributed to larger than typical BMI growth in the right tail of the distribution.

\section{Trends in Obesity and Severe Obesity}

The average BMI of 20-74 year olds changed little between 1960-1962 and 1976-1980 (rising just $0.26 \mathrm{~kg} / \mathrm{m}^{2}$ ) but increased much more rapidly thereafter: by $1.26 \mathrm{~kg} / \mathrm{m}^{2}$ between 1976-1980 and 1988-1994 and $1.61 \mathrm{~kg} / \mathrm{m}^{2}$ from 1988-1994 to 1999-2004 (see Table 1). On an 
annualized basis, body mass index grew over 50 percent faster from 1988-1994 to 1999-2004 than between 1976-1980 and 1988-1994 (0.56 percent versus 0.37 percent per year).

Obesity and severe obesity have increased even more. The prevalence of overweight rose 43 percent between 1976-80 and 1999-2004, while obesity more than doubled and class 2, 3 and 4 obesity tripled, quadrupled and quintupled. ${ }^{10}$ To place this in perspective, class 2 obesity was nearly as prevalent in 1999-2004 as obesity had been two decades earlier; class 3 obesity was more frequent than class 2 obesity had been at that time; and class 4 obesity rose from a clinical rarity to affecting over two percent of the population.

Figure 1 demonstrates that the particularly large rise of severe obesity reflects a shift in the overall BMI distribution, combined with increasing skewness, resulting in a much thicker right tail. This provides preliminary evidence of the roles of both general and concentrated weight gains in explaining the growth in extreme obesity. Figure 2 shows that the height of U.S. adults changed little during the period of rapidly rising obesity: in $1976-1980$, the $10^{\text {th }}, 50^{\text {th }}, 90^{\text {th }}$ and $99^{\text {th }}$ percentiles of the height distribution were $156.0,167.8,181.2$ and $190.0 \mathrm{~cm}$, compared to $156.7,168.8,182.8$, and $191.5 \mathrm{~cm}$ in 1999-2004. By contrast, weight rose $4.1 \mathrm{~kg}$ (from 53.3 to $57.4 \mathrm{~kg}$ ) at the $10^{\text {th }}$ percentile, and $8.3 \mathrm{~kg}$ (from 70.2 to $78.5 \mathrm{~kg}$ ), $15.5 \mathrm{~kg}$ (from 91.9 to 107.3 $\mathrm{kg}$ ) and $27.3 \mathrm{~kg}$ (from 116.4 to $143.6 \mathrm{~kg}$ ) at the $50^{\text {th }}, 90^{\text {th }}$ and $99^{\text {th }}$ percentiles.

The overall pattern of stable weight prior to NHANES 2 and rapid increases thereafter was observed for both sexes (see Table 2) but two differences are noteworthy. First, as previously recognized, males were somewhat more likely than women to be overweight but were much less frequently obese or severely obese (Flegal et al., 1998; Hedley et al, 2004; Must et al.,

\footnotetext{
${ }^{10}$ Results for 1971-1975 are very similar to $1976-1980$ and so are not displayed on this or future tables. For instance, average BMI was $25.30 \mathrm{~kg} / \mathrm{m}^{2}$, overweight prevalence was 46.56 percent and obesity and class 3 obesity prevalence were 14.30 and 1.29 percent respectively.
} 
1999): in 1999-2004, the prevalences of class 3 and 4 obesity were 6.9 and 2.9 percent for women compared to 3.3 and 1.2 percent for men. Second, weight increased faster over time for females than males. Between 1976-1980 and 1999-2004, average BMI rose 12.7 percent for women compared to 9.9 percent for men. This reflected larger growth for females at all points of the BMI distribution except the very highest: BMI rose 6.2, 9.0, 12.6, 16.2 and 16.9 percent at the $10^{\text {th }}, 25^{\text {th }}, 50^{\text {th }}, 75^{\text {th }}$ and $90^{\text {th }}$ percentile for women, compared to $4.3,7.1,8.8,10.8$ and 14.4 percent for men. $^{11}$

Age-adjusting the data to the 2000 Census population, using the age groups 20-39, 40-59 and 60-74, slightly increases BMI and obesity prevalence but does not change the basic trends. For instance, age-adjusted BMI averaged 25.16, 25.58 and 28.29 kg/m² in 1960-62, 1976-1980 and 1999-2004 (results not shown on a table). The corresponding prevalence of obesity was 13.8, 15.4 and 31.9 percent and that of class 3 obesity was $0.9,1.4$ and 5.2 percent.

\section{Future Forecasts of Obesity and Severe Obesity}

Table 3 displays forecasts of median BMI and the prevalence of overweight and various classes of obesity in 2001, 2010 and 2020. Projections for 2001 are similar to actual 1999-2004 rates (shown in the first column), indicating that the prediction procedures work well within the sample period: the actual value is outside the forecast 95 percent confidence interval in only one of 18 cases (obesity prevalence of females) and the differences are generally small. For example, 65.5 percent of 20-74 year olds were overweight and 31.5 percent were obese in 19992004, compared to the 2001 predictions of 65.2 and 30.0 percent. The projected prevalences of

\footnotetext{
${ }^{11}$ Median height rose $0.8 \mathrm{~cm}$ for males and $1.1 \mathrm{~cm}$ for females between 1976-1980 and 1999-2004. This was accompanied by rapid weight gains of $7.4,11.6,15.1$ and $19.4 \mathrm{~kg}$ at the $50^{\text {th }}, 75^{\text {th }}, 90^{\text {th }}$ and $95^{\text {th }}$ percentile for men and 8.3, 12.5, 16.9 and $19.4 \mathrm{~kg}$ for women.
} 
class 2, 3 and 4 obesity in 2001 (12.1, 4.8 and 1.9 percent) were all slightly below the rates observed in NHANES 99 (13.0, 5.2 and 2.1 percent). A likely reason is that the predictions are based on a linear time trend, while the evidence indicates that the secular increase in weight is accelerating. This suggests that the point forecasts for moderate and severe obesity prevalence in 2010 and 2020 may be slightly understated. ${ }^{12}$

Body weight is projected to grow rapidly during the first two decades of the $21^{\text {st }}$ century. Median male BMI is expected to be 1.8 percent $\left(0.5 \mathrm{~kg} / \mathrm{m}^{2}\right)$ greater in 2010 than in $1999-2004$, while the median BMI of females is predicted to rise 2.2 percent $\left(0.6 \mathrm{~kg} / \mathrm{m}^{2}\right)$. By 2020, median BMI is anticipated to be 5.1 percent $\left(1.4 \mathrm{~kg} / \mathrm{m}^{2}\right)$ higher than in $1999-2004$ for men and 6.3 percent $\left(1.7 \mathrm{~kg} / \mathrm{m}^{2}\right)$ greater for women. Based on current trends, 78 percent of men and 71 percent of women will be overweight in 2020.

Severe forms of excess weight are expected to rise much more. Obesity is forecasted to grow from 28.7 (34.1) percent of males (females) in 1999-2004 to 40.2 (43.3) percent in 2020. Class 2 obesity is estimated to climb over 70 percent for men (from 9.6 to 16.4 percent) and 57 percent for women (from 16.1 to 25.3 percent). Class 3 obesity is anticipated to rise more than 80 percent for both males (from 3.3 to 6.3 percent) and females (from 6.9 to 12.8 percent), with class 4 obesity more than doubling (from 1.2 to 3.1 percent for men and from 2.9 to 5.8 percent for women).

As mentioned, the preceding estimates assumed a linear time trend and so did not adjust for the accelerating growth in body weight occurring at the end of the $20^{\text {th }}$ century. Accounting

\footnotetext{
12 An additional downwards bias is likely due to changes in population characteristics that will occur between 1999-2004 and 2020 but are not accounted for. Consistent with this, corresponding 2001-year forecasts, based on 1976-1980 population characteristics, are always below the actual results for the NHANES 99 period - e.g. predicted obesity and class 3 obesity prevalence is 28.8 and 4.67 percent, versus observed rates of 31.5 and 5.17 percent. The understatement is largely due to not accounting for rapid growth in the population share of Hispanics - rising from 5.2 to 13.6 percent between 1976-1980 and 1999-2004 - who are relatively often obese.
} 
for such nonlinearities yields still higher estimates of future obesity. For instance, in a second set of projections using the same methods but measuring trends over the shorter period covered by NHANES 3 and 99 only (1988-94 through 1999-2004), 45.1 percent of men and 48.6 percent of women are forecasted to be obese in 2020, with class 2, 3 and 4 obesity predicted for 19.2, 7.9 and 3.3 percent of men and 29.3, 13.8 and 6.4 percent of women (see Appendix Table A.1). Even larger future obesity rates are obtained using other specifications, such as including a quadratic time trend for the NHANES 2 through 99 period.

\section{General Versus Concentrated Weight Gains}

Class 3 obesity quadrupled and class 4 obesity quintupled between 1976-80 and 19992004. This was mostly due to abnormally large weight increases at the top of the BMI distribution, rather than a general rise in body weight, and contrasts with the more dominant role of dispersed changes in explaining the corresponding growth in overweight and mild obesity. These findings are documented in Table 4. Median BMI and overweight/obesity prevalence during the NHANES 2 period are shown in column (a). Column (b) displays corresponding statistics predicted for 1976-1980, assuming the race/ethnicity and age characteristics of the 1999-2004 population. ${ }^{13}$ Column (c) indicates expected values in 2001, using 1976-1980 population characteristics but adjusted for predicted sex-specific median growth in BMI occurring between 1978 (the midpoint of NHANES 2) and 2001. ${ }^{14}$ Actual 1999-2004 median BMI and prevalence rates are displayed in column (d). Column (e) shows the estimates of secular increases attributed to concentrated (rather than general) weight gains. These are

\footnotetext{
13 These are obtained using the previously described quantile regression methods for the NHANES 99 sample but with the time trend variable set to 1978 .

${ }^{14}$ Median BMI is predicted to rise $0.0844(0.1027) \mathrm{kg} / \mathrm{m}^{2}$ per year for men (women).
} 
calculated by subtracting from the total growth (column $\mathrm{d}$ - column a), the proportions due to changing population characteristics (column b - column a) and rising median BMI (column c column a). To illustrate, obesity prevalence increased 17.0 percentage points (from 14.5 to 31.5 percent) between 1976-1980 and 1999-2004, with -0.4 points of this due to changing population characteristics and 9.8 points reflecting growth in median BMI. The remaining 7.6 percentage points are therefore attributed to concentrated weight gains and this accounts for 44.4 percent of the total rise in obesity. ${ }^{15}$

General growth in body weight accounted for around 90 percent of the increase in median BMI, between 1976-1980 and 1999-2004, and more than 100 percent of the rise in overweight. The importance of dispersed weight gains for these outcomes is unsurprising, since more than half of males and two-fifths of females were overweight at the beginning of the analysis period.

Conversely, increases in severe obesity prevalence mainly resulted from concentrated weight gains: these are responsible for 65, 79 and 77 percent of the growth in class 2, class 3 and class 4 obesity. This is particularly true for men but increases in the right tail of the BMI distribution explain at least three-fifths of the growth for both sexes. ${ }^{16}$

Table 5 details corresponding decompositions of the increases in prevalences of overweight and obesity forecasted to occur between 1999-2004 and 2020. Column (a) shows actual statistics for the NHANES 99 period and column (c) provides projections for 2020 previously obtained from the quantile regressions. Column (b) indicates rates expected in 2020 under the assumption that the BMI of all adults will increase at the predicted sex-specific median

\footnotetext{
15 The statistics were calculated to six significant digits, with some differences in the table due to rounding error.

16 Median BMI increased faster for women than men and so explains a greater portion of rising prevalence rates of females. Concentrated weight growth also accounts for 23 percent (20 percent for men and 27 percent for women)
} 
(1.85 kg/m ${ }^{2}$ for males and $2.37 \mathrm{~kg} / \mathrm{m}^{2}$ for females), rather than using the larger growth anticipated in the right tail of the BMI distribution. The proportion of the change due to concentrated weight gains, shown in column (d), is then calculated as the difference between the total predicted increase (column c - column a) and that resulting from median BMI growth (column b- column a). ${ }^{17}$

Predicted increases in severe obesity are again dominated by weight gains in the right tail of the BMI distribution: these account for half the predicted growth in class 3 obesity and twothirds of the rise in class 4 prevalence, with even higher contributions for males. By contrast, the increase anticipated for overweight and mild obesity entirely results from general weight gains. This occurs because a large majority of adults are overweight in 1999-2004 and so these prevalences are less affected by experiences at the extremes of the distribution.

\section{Discussion}

Obesity became ubiquitous during the last quarter of the $20^{\text {th }}$ century - prevalence rates for 20-74 year olds rose from 15 percent in 1976-1980 to 32 percent in 1999-2004 - following a period of relatively stable weight. If these trends continue, 33 percent of men and 38 percent of women will be obese in 2010, with predicted prevalences of 40 and 43 percent in 2020. To provide perspective, the Healthy People 2010 target is to lower the prevalence of adult obesity to 15 percent (US Department of Health and Human Services, 2000).

Even more significant are the increases forecasted for severe forms of excess weight. Class 3 obesity, sometimes referred to as “morbid” obesity, was unusual in the late 1970s -

of the growth in class 1 obesity (BMI: 30.0-34.9).

17 Since the 2020 forecasts were obtained using 1999-2004 population characteristics, no additional correction is included for changes in the age and race/ethnicity characteristics of the population. 
affecting just over one percent of 20-74 year olds - but prevalence surpassed 3 percent of men and 6 percent of women at the turn of the $21^{\text {st }}$ century, and is predicted to exceed 6 percent of males and approach 13 percent of females in 2020.

There are currently no generally accepted US or international standards for excess weight beyond class 3 obesity but the rapid growth in BMI suggests the importance of classifying and monitoring such extremes. To illustrate, the prevalence of “class 4” obesity, defined as $\mathrm{BMI} \geq 45$, increased from 0.4 percent of 20-74 year olds in 1976-1980 to 2.1 percent in 19992004, and is forecasted to reach 4.4 percent in 2020. For women, the prevalence of class 4 obesity was 2.9 percent in 1999-2004 and is predicted to be 5.8 percent in 2020 .

Extreme obesity represents a particular public health risk. In 2000, approximately nine million 20-74 year olds had class 3 (or higher) obesity, making them potential candidates for extreme interventions, such as antiobesity surgery (National Institutes of Health Consensus Development Conference, 1992). The projections above indicate that the corresponding number will exceed 17 million in 2020, even abstracting from future population growth. Some (but not all) negative health consequences of obesity may be declining over time but the risks remain much higher for obese than non-obese individuals and a portion of the reduction is probably due to medical interventions that raise health care costs (Gregg et al., 2005; Henderson, 2005). Moreover, the medical problems associated with high BMI may be larger for women than men (Flegal, 2006), raising additional concern about the particularly high prevalence of severe obesity among females.

Between 1976-80 and 1999-2004, class 3 obesity quadrupled and class 4 obesity quintupled. This was mostly due to especially large weight increases at the top of the BMI 
distribution, rather than to more general growth in body weight. To illustrate, if BMI had increased at the sex-specific median for all adults, the prevalences of class 3 and 4 obesity would have been 2.2 and 0.7 percent in 1999-2004, rather than 5.2 and 2.1 percent. Projecting forward from the actual rates in NHANES 99, BMI growth at the projected sex-specific median across all individuals (rather than at the higher amounts expected for heavier persons) would imply class 3 and class 4 obesity rates of 7.4 and 2.8 percent in 2020, substantially below the forecasted prevalences of 9.6 and 4.4 percent.

Some analysts suggest that interventions designed to reverse the obesity epidemic should “focus on the population rather than solely on the heaviest individuals" (Flegal and Troiano, 2000, p. 818). Others believe this can be accomplished with "small behavior changes that fit relatively easily into most people’s lifestyles” (Hill et al., 2003, p. 855). By contrast, this analysis suggests that such population-wide changes may reduce the future growth in overweight and mild obesity but will be less effective in combating the rise in severe obesity. Doing so is likely to require additional strategies targeting the especially large weight gains of the heaviest individuals, probably involving substantial behavior modifications or medical interventions. Additional monitoring of extreme obesity represents an important first step. Even the analysis of class 4 obesity presented above may be inadequate, given the rapid growth of the highest levels of body weight. For instance, 1.0 percent of 20-74 year old women had BMI $\geq 50$ in 1999-2004 but 2.4 percent were projected (using quantile regression techniques) to exceed this threshold in 2020 . Future research also needs to examine whether there are differences in the energy balance of normal weight or overweight and mildly obese individuals, compared to those who are severely obese. For example, evidence that class 3 or 4 obesity primarily results 
from high levels of energy intake would suggest the importance of reducing calories consumed or absorbed, although presumably accompanied by efforts to raise energy expenditure.

These findings should be evaluated in light of several methodological limitations. First this study examines BMI rather than more accurate measures of body composition. However, the resulting errors are likely to be quite small when considering severe obesity. To illustrate, note that waist circumference exceeding 102 (88) cm for men (women) represents a separate obesity risk factor (Freedman et al, 2000; Janssen et al., 2002; Sönmez et al., 2003; Dalton, 2003). By this standard, 39.1 percent of males and 58.5 percent of women were at risk in 19992004, compared to projections (using the quantile regression methods) of 56.2 and 72.4 percent in 2020. Moreover, while 52 percent of overweight but non-obese (BMI: 25.0-29.9) adults in NHANES 3 and 99 had waist sizes below the threshold, the same was true of less than 8 percent of the class 1 obese (BMI: 30.0 - 34.9) and 0.3 percent of those with class 2 or higher obesity. Second, the forecasts of future obesity and severe obesity prevalence were based on characteristics of the 1999-2004 population and so did not account for anticipated demographic changes, the most important of which are probably population aging and growth in the share of Hispanics. Accounting for these would probably result in an additional increase in future prevalence forecasts, although it is not obvious by how much. ${ }^{18}$

Third, the future obesity projections used extrapolations of prior trends but without identifying the sources for them. It is possible that the factors increasing obesity during the last quarter of the $20^{\text {th }}$ century will be ameliorated over the next two decades. Indeed, an important goal of public health policies and medical interventions is to do precisely this. However,

\footnotetext{
${ }^{18}$ Projecting future population trends is always difficult. In addition, Hispanics have relatively high rates of obesity but not class 3 obesity (Ogden et al., 2006), while obesity and severe obesity reach their highest levels during late middle-age (Freedman et al., 2002; Flegal et al., 2002).
} 
evidence of the recent success of these efforts is mixed at best. Ogden et al. (2006), using data from NHANES 99, find that the overweight and obesity prevalence of adult females did not increase by statistically significant amounts between 1999 and 2004; however, male obesity continued to rise and the sample sizes for the time periods examined were too small to reject the possibility that large increases occurred. Using much larger samples, but self-report data, Sturm (forthcoming) indicates that the growth of moderate and severe obesity continued to accelerate after the turn of the century, which is consistent with available evidence analyzing longer time periods. This suggests that future rates of obesity and severe obesity may be even higher than those predicted by this analysis. Subsequent research is likely to arrive at more sophisticated forecasts by examining how obesity trends vary with population characteristics, across geographic locations, and by accounting more fully for lifecycle changes in body weight, variations in specific components of the energy balance across types of individuals, and personal decisions relating to energy intake and expenditure. 


\section{REFERENCES}

Allison DB, Fontaine KR, Manson JE, Stevens J, VanItallie TB. Annual deaths attributable to obesity in the United States. JAMA 1999; 282: 1530-1538.

Anderson PM, Butcher KF, Levine PB. Economic perspectives on childhood obesity. Federal Reserve Bank of Chicago: Economic Perspectives 2003; 27(3): 30-48.

Andreyeva T, Sturm R, Ringel JS. Moderate and severe obesity have large differences in health care costs. Obes Res 2004; 12: 1936-1943.

Calle EF, Thun MJ, Petrelli JM, Rodriguez C, Heath CW. Body-mass index and mortality in a prospective cohort of US adults. N Engl J Med 1999; 341: 1097-1105.

Cawley J, Burkhauser RV. Beyond BMI: The Value of More Accurate Measures of Fatness and Obesity in Social Science Research. National Bureau of Economic Research Working Paper No. 12291, July 2006.

Cox BD, Whichelow, MJ. Ratio of Waist Circumference to Height is Better Predictor of Death than Body Mass Index. British Medical Journal 313(7070), December 17, 1996, 1487-1488.

Dalton M, Cameron AJ, Zimmet PZ, et al; on behalf of the Ausdiab Steering Committee. Waist circumference, waist-hip ratio and body mass index and their correlations with cardiovascular disease risk factors in Australian adults. J Intern Med 2003; 254: 555-563.

Engeland A, Bjøge T, Selmer RM, Tverdal A. Height and body mass index in relation to total mortality. Epidemiology 2003; 14: 293-299.

Finkelstein EA, Fiebelkorn IC, Wang G. "national medical spending attributable to overweight and obesity: how much, and who’s paying. Health Affairs 2003; web exclusive: w3.219w3.226.

Flegal KM. Body mass index of healthy men compared with healthy women in the United States. Int J Obes 2006; 30: 374-379.

Flegal KM, Carroll MD, Kuczmarski RJ, Johnson, CL. Overweight and obesity in the United States: prevalence and trends, 1960-1994. Int J Obes 1998; 22: 39-47.

Flegal KM, Carroll MD, Ogden CL, Johnson CL. Prevalence and trends in obesity among US adults, 1999-2000. JAMA 2002; 288: 1723-1727.

Flegal KM, Graubard BI, Williamson DF, Gail MH. Excess deaths associated with underweight, overweight, and obesity. JAMA 2005; 293: 1861-7.

Flegal KM, Troiano, RP. Changes in the distribution of body mass index of adults and children in the US population. Int J Obes 2000; 24: 807-818. 
Fontaine KR, Redden DT, Wang C, Westfall AO, Allison DB. Years of life lost due to obesity. JAMA 2003; 289: 187-193.

Freedman DS, Khan LK, Serdula MK, Galuska DA, Dietz WH. Trends and correlates of class 3 obesity in the United States from 1900 through 2000. JAMA 2002; 288: 1758-1762.

Goodman E, Hinden BR, Khandelwal, S Accuracy of Teen and Parental Reports of Obesity and Body Mass Index. Pediatrics 106(1), July 2000: 52-58.

Gregg EW, Cheng YJ, Cadwell B, et al. Secular trends in cardiovascular disease risk factors according to body mass index in US adults. JAMA 2005; 293: 1868-1874.

Hedley AA, Ogden CL, Johnson CL, Carroll MD, Curtin LR, Flegal KM. Prevalence of overweight and obesity among US children, adolescents, and adults, 1999-2002. JAMA 2004; 291: 2847-2850.

Henderson RM. The bigger the healthier: are the limits of BMI risk changing over time? Econ Hum Biol 2005; 3:339-366.

Hill JO, Wyatt HR, Reed GW, Peters JC. Obesity and the environment: where do we go from here? Science 2003; 5608: 853-855.

International Obesity Task Force. EU Platform on Diet, Physical Activity and Health. Brussels: International Obesity Task Force; 2005.

Janssen I, Katzmarzyk PT, Ross R. Body mass index, waist circumference, and health risk: evidence in support of current national institutes of health guidelines. Arch Intern Med 2002; 162: 2074-2079.

Koenker R, Hallock KF. Quantile regression. J Econ Perspect 2001; 15: 143-156.

Kuczmarski MF, Kuczmarski RJ, Najjar M. Effects of Age on Validity of Self-Reported Height, Weight, and Body Mass Index: Findings from the Third Health and Nutrition Examination Survey, 1988-1994. Journal of the American Dietetic Association 101(1), January 2000: 2834.

McDowell A, Engel A, Massey JT, Maurer K. Plan and operation of the Second National Health and Nutrition Examination Survey, 1976-1980. Vital Health Stat 11981 series 1(15): 1144.

Manning WG., Blumberg L, and Moulton LH. The demand for alcohol: the differential response to price. J Health Econ 1995; 14: 123-148.

Miller HW. Plan and operation of the Health and Nutrition Examination Survey, United States. Vital Health Stat 1 1973; 1: 1-46.

Mokdad AH, Bowman BA, Ford ES, Vinicor F, Marks JS, Koplan, JP. The continuing epidemics of obesity and diabetes in the United States. JAMA 2001; 286: 1195-1200 
Mokdad AH, Ford ES, Bowman BA, Dietz WH, Vinicor F, Bales VS, Marks JS. Prevalence of obesity, diabetes, and obesity-related risk factors, 2001 JAMA. 2003; 289: 76-79.

Must A, Spadano J, Coakley EH, Field AE, Colditz G, Dietz WH. The disease burden associated with overweight and obesity. JAMA 1999; 282: 1523-1529.

National Center for Health Statistics. Plan and initial program of the Health Examination Survey. Vital Health Stat 1 1965; 4: 1-43.

National Center for Health Statistics. Public use data tape documentation: physical measurements 1 tape number 1003, National Health Examination Survey, 1959-1962, May 1981; accessed from: http://www.cdc.gov/nchs/data/nhanes/nhes123/1003.pdf.

National Center for Health Statistics. Plan and operation of the third National Health and Nutrition Examination Survey, 1988-94; series 1: programs and collection procedures. Vital Health Stat 1 1994; 32: 1-407.

National Heart, Lung, and Blood Institute. Clinical Guidelines on the Identification, Evaluation, and Treatment of Overweight and Obesity in Adults: The Evidence Report. Washington D.C.: US Government Printing Office; 1998.

National Institutes of Health Consensus Development Conference. Gastrointestinal surgery for severe obesity: National Institutes of Health consensus development conference statement. Am J Clin Nutr 1992; 55: 615s-619s.

Ogden CL, Carroll MD, Curtin, LR et al. Prevalence of overweight and obesity in the United States, 1999-2004. JAMA 2006; 295: 1549-1555.

Olshansky SJ, Passaro DJ, Hershow RC, Layden J, Carnes BA, Brody J, et al. A potential decline in life expectancy in the United States in the $21^{\text {st }}$ century. $N$ Engl J Med, 2005; 352: 1138-1145.

Okoro CA, Hootman JM, Strine TW, Ballus LS, Mokdad AH. Disability, arthritis, and body weight among adults 45 years and older. Obes Res 2004; 12: 854-861.

Peeters A, Barendregt JJ, Willekens F, Mackenbach JP, et al; for the Netherlands Epidemiology and Demography Compression Of Morbidity Research Group. Obesity in adulthood and it's consequences for life expectancy: a life-table analysis” Ann Intern Med 2003; 138: 24-32.

Sönmez K, Akcakoyun M, Akcay A, et al. Which method should be used to determine the obesity, in patients with coronary artery disease? (body mass index, waist circumference or waist-hip ratio). Int J Obes 2003; 27, 341-346.

StataCorp. Stata Statistical Software: Release 9. College Station, TX: Stata Corporation, 2005.

Strauss RS. Comparison of measured and self-reported weight and height in a cross-sectional sample of young adolescents. ” Int J Obes 1999; 23(8): 904-908. 
Sturm R. Increases in clinically severe obesity in the United States, 1986-2000. Arch Intern Med 2003; 163: 2146-2148.

Sturm, R. Increases in morbid obesity in the USA: 2000-2005. Public Health, forthcoming.

Quesenberry CP, Caan B, Jacobson A. Obesity, health dervices use, and health care costs among members of a health maintenance organization. Arch Intern Med 1998; 158: 466-472.

Thompson D, Brown JB, Nichols GA, Elmer PJ, Oster G. Body mass index and future healthcare costs: a retrospective cohort study Obes Res 2001; 9: 210-18.

US Department of Health and Human Services. Healthy People 2010. 2nd ed. With Understanding and Improving Health and Objectives for Improving Health. Washington, DC: US Government Printing Office; 2000.

World Health Organization. Obesity: Preventing and Managing the Global Epidemic. Report of a WHO Consultation on Obesity. Geneva, Switzerland: World Health Organization; 1997. 
Table 1. Trends in Body Mass Index and Excess Weight for 20-74 Year Olds

\begin{tabular}{|c|c|c|c|c|c|c|}
\hline $\begin{array}{l}\text { Time Period (Data } \\
\text { Source) }\end{array}$ & $\begin{array}{l}\text { Body } \\
\text { Mass } \\
\text { Index } \\
\text { (BMI) }\end{array}$ & $\begin{array}{c}\text { Over- } \\
\text { weight } \\
(\mathrm{BMI} \geq 25)\end{array}$ & $\begin{array}{c}\text { Obese } \\
(\mathrm{BMI} \geq 30)\end{array}$ & $\begin{array}{c}\text { Obese: } \\
\text { Class } 2 \\
(\mathrm{BMI} \geq 35)\end{array}$ & $\begin{array}{c}\text { Obese: } \\
\text { Class } 3 \\
(\mathrm{BMI} \geq 40)\end{array}$ & $\begin{array}{c}\text { Obese: } \\
\text { Class } 4 \\
(\mathrm{BMI} \geq 45)\end{array}$ \\
\hline \multicolumn{7}{|c|}{ Average/Prevalence Rate } \\
\hline 1960-1962 (NHES 1) & $\begin{array}{l}25.05 \\
(0.08)\end{array}$ & $\begin{array}{c}45.27 \% \\
(0.80)\end{array}$ & $\begin{array}{c}13.41 \% \\
(0.53)\end{array}$ & $\begin{array}{l}3.35 \% \\
(0.22)\end{array}$ & $\begin{array}{l}0.88 \% \\
(0.13)\end{array}$ & $\begin{array}{l}0.28 \% \\
(0.09)\end{array}$ \\
\hline 1976-1980 (NHANES 2) & $\begin{array}{l}25.31 \\
(0.07)\end{array}$ & $\begin{array}{c}45.91 \% \\
(0.83)\end{array}$ & $\begin{array}{c}14.48 \% \\
(0.41)\end{array}$ & $\begin{array}{l}4.42 \% \\
(0.16)\end{array}$ & $\begin{array}{l}1.30 \% \\
(0.13)\end{array}$ & $\begin{array}{l}0.42 \% \\
(0.09)\end{array}$ \\
\hline 1988-1994 (NHANES 3) & $\begin{array}{l}26.57 \\
(0.12)\end{array}$ & $\begin{array}{c}54.59 \% \\
(0.92)\end{array}$ & $\begin{array}{l}22.39 \% \\
(0.72)\end{array}$ & $\begin{array}{l}8.12 \% \\
(0.54)\end{array}$ & $\begin{array}{l}2.91 \% \\
(0.25)\end{array}$ & $\begin{array}{l}1.02 \% \\
(0.14)\end{array}$ \\
\hline 1999-2004 (NHANES 99) & $\begin{array}{l}28.18 \\
(0.11)\end{array}$ & $\begin{array}{c}65.45 \% \\
(0.65)\end{array}$ & $\begin{array}{c}31.51 \% \\
(0.77)\end{array}$ & $\begin{array}{c}12.95 \% \\
(0.51)\end{array}$ & $\begin{array}{l}5.17 \% \\
(0.32)\end{array}$ & $\begin{array}{l}2.07 \% \\
(0.20)\end{array}$ \\
\hline \multicolumn{7}{|c|}{ \% Change } \\
\hline $1960-1962$ to $1976-1980$ & $1.06 \%$ & $1.43 \%$ & $7.98 \%$ & $32.16 \%$ & $48.72 \%$ & $48.16 \%$ \\
\hline $1976-1980$ to $1988-1994$ & $4.95 \%$ & $18.90 \%$ & $54.59 \%$ & $83.46 \%$ & $123.45 \%$ & $143.67 \%$ \\
\hline $1988-1994$ to $1999-2004$ & $6.07 \%$ & $19.90 \%$ & $40.75 \%$ & $59.60 \%$ & $77.56 \%$ & $103.42 \%$ \\
\hline \multicolumn{7}{|c|}{ Annual Growth Rate } \\
\hline $1960-1962$ to $1976-1980$ & $0.06 \%$ & $0.08 \%$ & $0.45 \%$ & $1.65 \%$ & $2.36 \%$ & $2.34 \%$ \\
\hline $1976-1980$ to $1988-1994$ & $0.37 \%$ & $1.34 \%$ & $3.41 \%$ & $4.78 \%$ & $6.38 \%$ & $7.09 \%$ \\
\hline 1988-1994 to $1999-2004$ & $0.56 \%$ & $1.74 \%$ & $3.31 \%$ & $4.55 \%$ & $5.62 \%$ & $7.00 \%$ \\
\hline
\end{tabular}

Note: NHES 1 indicates the first National Health Examination Survey and NHANES the National Health and Nutrition Examination Surveys. Sample sizes for NHES 1 and NHANES 2, 3 and 99 are 6,257, $1,1864,14,756$ and 12,025 . BMI is weight in kilograms divided by height in meters squared. The data are weighted to provide nationally representative estimates and standard errors, displayed in parentheses, are corrected for complex survey design. Annual percent changes are calculated assuming a 17-year time difference between 1960-62 and 1976-80, a 13-year difference between 1976-80 and 1988-94, and a 10.5year difference between 1988-94 and 1999-2004. 
Table 2. Trends in Body Mass Index and Excess Weight for 20-74 Year Olds, By Sex

\begin{tabular}{|c|c|c|c|c|c|c|}
\hline Time Period & $\begin{array}{l}\text { Body Mass } \\
\text { Index } \\
\text { (BMI) }\end{array}$ & $\begin{array}{c}\text { Over- } \\
\text { weight } \\
(\mathrm{BMI} \geq 25)\end{array}$ & $\begin{array}{c}\text { Obese } \\
(\mathrm{BMI} \geq 30)\end{array}$ & $\begin{array}{c}\text { Obese: } \\
\text { Class } 2 \\
(\mathrm{BMI} \geq 35)\end{array}$ & $\begin{array}{c}\text { Obese: } \\
\text { Class } 3 \\
(\mathrm{BMI} \geq 40)\end{array}$ & $\begin{array}{c}\text { Obese: } \\
\text { Class } 4 \\
(\mathrm{BMI} \geq 45)\end{array}$ \\
\hline \multicolumn{7}{|c|}{ Males } \\
\hline $1960-1962$ & $\begin{array}{l}25.15 \\
(0.09)\end{array}$ & $\begin{array}{c}49.42 \% \\
(1.13)\end{array}$ & $\begin{array}{c}10.66 \% \\
(0.73)\end{array}$ & $\begin{array}{l}1.49 \% \\
(0.23)\end{array}$ & $\begin{array}{l}0.29 \% \\
(0.11)\end{array}$ & $\begin{array}{l}0.15 \% \\
(0.10)\end{array}$ \\
\hline $1976-1980$ & $\begin{array}{l}25.48 \\
(0.07)\end{array}$ & $\begin{array}{c}51.06 \% \\
(0.95)\end{array}$ & $\begin{array}{c}12.07 \% \\
(0.55)\end{array}$ & $\begin{array}{l}2.30 \% \\
(0.20)\end{array}$ & $\begin{array}{l}0.40 \% \\
(0.08)\end{array}$ & $\begin{array}{l}0.06 \% \\
(0.04)\end{array}$ \\
\hline 1988-1994 & $\begin{array}{l}26.63 \\
(0.11)\end{array}$ & $\begin{array}{c}59.10 \% \\
(1.07)\end{array}$ & $\begin{array}{c}19.64 \% \\
(0.71)\end{array}$ & $\begin{array}{l}5.31 \% \\
(0.55)\end{array}$ & $\begin{array}{l}1.80 \% \\
(0.33)\end{array}$ & $\begin{array}{l}0.53 \% \\
(0.17)\end{array}$ \\
\hline 1999-2004 & $\begin{array}{l}28.00 \\
(0.10)\end{array}$ & $\begin{array}{c}69.09 \% \\
(0.76)\end{array}$ & $\begin{array}{c}28.74 \% \\
(0.77)\end{array}$ & $\begin{array}{l}9.61 \% \\
(0.59)\end{array}$ & $\begin{array}{l}3.34 \% \\
(0.36)\end{array}$ & $\begin{array}{l}1.23 \% \\
(0.19)\end{array}$ \\
\hline \multicolumn{7}{|c|}{ Females } \\
\hline 1960-1962 & $\begin{array}{l}24.95 \\
(0.11)\end{array}$ & $\begin{array}{c}41.51 \% \\
(1.07)\end{array}$ & $\begin{array}{c}15.90 \% \\
(0.59)\end{array}$ & $\begin{array}{l}5.03 \% \\
(0.41)\end{array}$ & $\begin{array}{l}1.41 \% \\
(0.19)\end{array}$ & $\begin{array}{l}0.40 \% \\
(0.11)\end{array}$ \\
\hline 1976-1980 & $\begin{array}{l}25.16 \\
(0.11)\end{array}$ & $\begin{array}{c}41.23 \% \\
(1.00)\end{array}$ & $\begin{array}{c}16.68 \% \\
(0.56)\end{array}$ & $\begin{array}{l}6.35 \% \\
(0.28)\end{array}$ & $\begin{array}{l}2.13 \% \\
(0.24)\end{array}$ & $\begin{array}{l}0.75 \% \\
(0.17)\end{array}$ \\
\hline 1988-1994 & $\begin{array}{l}26.50 \\
(0.17)\end{array}$ & $\begin{array}{c}50.37 \% \\
(1.14)\end{array}$ & $\begin{array}{c}24.96 \% \\
(1.05)\end{array}$ & $\begin{array}{c}10.75 \% \\
(0.78)\end{array}$ & $\begin{array}{l}3.95 \% \\
(0.34)\end{array}$ & $\begin{array}{l}1.47 \% \\
(0.22)\end{array}$ \\
\hline 1999-2004 & $\begin{array}{l}28.35 \\
(0.14)\end{array}$ & $\begin{array}{l}62.01 \\
(0.95)\end{array}$ & $\begin{array}{c}34.14 \% \\
(1.00)\end{array}$ & $\begin{array}{c}16.12 \% \\
(0.66)\end{array}$ & $\begin{array}{l}6.91 \% \\
(0.44)\end{array}$ & $\begin{array}{l}2.88 \% \\
(0.29)\end{array}$ \\
\hline
\end{tabular}

Note: See note on Table 1. Sample sizes for NHES 1 and NHANES 2, 3 and 99 are 2,895, 5,604, 6,916 and 5,696 for males and 3,362, 6,260, 7,840 and 6,329 for females. 
Table 3. Projected Future Prevalence of Excess Weight for 20-74 Year Olds, Based on 1999-2004 Population

\begin{tabular}{|c|c|c|c|c|}
\hline \multirow{2}{*}{ Outcome } & \multirow{2}{*}{$\begin{array}{c}\text { 1999-2004 } \\
\text { (Actual) }\end{array}$} & \multicolumn{3}{|c|}{ Projected: } \\
\hline & & 2001 & 2010 & 2020 \\
\hline \multicolumn{5}{|c|}{ Males } \\
\hline Median BMI & 27.3 & $\begin{array}{c}27.1 \\
{[26.8-27.3]}\end{array}$ & $\begin{array}{c}27.8 \\
{[27.5-28.1]}\end{array}$ & $\begin{array}{c}28.7 \\
{[28.3-29.0]}\end{array}$ \\
\hline Overweight & $69.1 \%$ & $\begin{array}{c}69.0 \% \\
{[67.0-70.8]}\end{array}$ & $\begin{array}{c}73.9 \% \\
{[71.3-76.2]}\end{array}$ & $\begin{array}{c}77.6 \% \\
{[75.3-80.5]}\end{array}$ \\
\hline Obese & $28.7 \%$ & $\begin{array}{c}27.4 \% \\
{[25.5-29.4]}\end{array}$ & $\begin{array}{c}33.0 \% \\
{[30.2-36.2]}\end{array}$ & $\begin{array}{c}40.2 \% \\
{[35.9-42.7]}\end{array}$ \\
\hline Obese: Class 2 & $9.61 \%$ & $\begin{array}{c}8.97 \% \\
{[7.49-10.2]}\end{array}$ & $\begin{array}{c}12.8 \% \\
{[11.2-14.1]}\end{array}$ & $\begin{array}{c}16.4 \% \\
{[14.6-18.9]}\end{array}$ \\
\hline Obese: Class 3 & $3.34 \%$ & $\begin{array}{c}3.15 \% \\
{[2.45-3.87]}\end{array}$ & $\begin{array}{c}4.77 \% \\
{[3.84-5.52]}\end{array}$ & $\begin{array}{c}6.27 \% \\
{[5.07-8.07]}\end{array}$ \\
\hline Obese: Class 4 & $1.23 \%$ & $\begin{array}{c}1.15 \% \\
{[0.44-1.55]}\end{array}$ & $\begin{array}{c}2.01 \% \\
{[1.03-2.51]}\end{array}$ & $\begin{array}{c}3.10 \% \\
{[2.31-3.99]}\end{array}$ \\
\hline \multicolumn{5}{|c|}{ Females } \\
\hline Median BMI & 26.9 & $\begin{array}{c}26.6 \\
{[26.3-26.9]}\end{array}$ & $\begin{array}{c}27.5 \\
{[27.1-28.0]}\end{array}$ & $\begin{array}{c}28.6 \\
{[28.0-29.1]}\end{array}$ \\
\hline Overweight & $62.0 \%$ & $\begin{array}{c}61.5 \% \\
{[59.7-63.5]}\end{array}$ & $\begin{array}{c}66.0 \% \\
{[64.2-68.2]}\end{array}$ & $\begin{array}{c}71.1 \% \\
{[68.1-73.2]}\end{array}$ \\
\hline Obese & $34.1 \%$ & $\begin{array}{c}32.4 \% \\
{[30.7-33.9]}\end{array}$ & $\begin{array}{c}37.8 \% \\
{[35.8-40.2]}\end{array}$ & $\begin{array}{c}43.3 \% \\
{[40.6-46.3]}\end{array}$ \\
\hline Obese: Class 2 & $16.1 \%$ & $\begin{array}{c}15.0 \% \\
{[13.3-16.3]}\end{array}$ & $\begin{array}{c}19.2 \% \\
{[17.0-20.9]}\end{array}$ & $\begin{array}{c}25.3 \% \\
{[21.9-27.8]}\end{array}$ \\
\hline Obese: Class 3 & $6.91 \%$ & $\begin{array}{c}6.40 \% \\
{[5.46-7.37]}\end{array}$ & $\begin{array}{c}9.12 \% \\
{[7.34-10.6]}\end{array}$ & $\begin{array}{c}12.8 \% \\
{[10.3-14.5]}\end{array}$ \\
\hline Obese: Class 4 & $2.88 \%$ & $\begin{array}{c}2.52 \% \\
{[1.82-3.15]}\end{array}$ & $\begin{array}{c}3.68 \% \\
{[2.82-4.66]}\end{array}$ & $\begin{array}{c}5.77 \% \\
{[4.08-7.19]}\end{array}$ \\
\hline \multicolumn{5}{|c|}{ Males and Females } \\
\hline Median BMI & 27.1 & $\begin{array}{c}26.9 \\
{[26.7-27.1]}\end{array}$ & $\begin{array}{c}27.8 \\
{[27.5-28.0]}\end{array}$ & $\begin{array}{c}28.7 \\
{[28.4-29.0]}\end{array}$ \\
\hline Overweight & $65.5 \%$ & $\begin{array}{c}65.2 \% \\
{[63.3-67.0]}\end{array}$ & $\begin{array}{c}69.9 \% \\
{[67.7-72.1]}\end{array}$ & $\begin{array}{c}74.3 \% \\
{[71.6-76.7]}\end{array}$ \\
\hline Obese & $31.5 \%$ & $\begin{array}{c}30.0 \% \\
{[28.2-31.7]}\end{array}$ & $\begin{array}{c}35.5 \% \\
{[33.1-38.3]}\end{array}$ & $\begin{array}{c}41.8 \% \\
{[38.3-44.6]}\end{array}$ \\
\hline Obese: Class 2 & $13.0 \%$ & $\begin{array}{c}12.1 \% \\
{[10.5-13.3]}\end{array}$ & $\begin{array}{c}16.1 \% \\
{[14.2-17.6]}\end{array}$ & $\begin{array}{c}21.0 \% \\
{[18.4-23.5]}\end{array}$ \\
\hline Obese: Class 3 & $5.17 \%$ & $\begin{array}{c}4.82 \% \\
{[4.00-5.67]}\end{array}$ & $\begin{array}{c}7.00 \% \\
{[5.66-8.12]}\end{array}$ & $\begin{array}{c}9.60 \% \\
{[7.75-11.4]}\end{array}$ \\
\hline Obese: Class 4 & $2.07 \%$ & $\begin{array}{c}1.86 \% \\
{[1.15-2.37]}\end{array}$ & $\begin{array}{c}2.87 \% \\
{[2.13-3.61]}\end{array}$ & $\begin{array}{c}4.37 \% \\
{[3.22-5.63]}\end{array}$ \\
\hline
\end{tabular}


Note: Table shows predicted prevalence rate in the specified year obtained from quantile regressions that include covariates for race/ethnicity, age and linear time trends showing years elapsed since 1975; 95 percent confidence intervals are shown in brackets. Projections are based on time trends for the period covered by the NHANES 2, 3 and 99 surveys, using methods described in the text, with race/ethnicity and age set to the average characteristics of the 1999-2004 population. 
Table 4. BMI and Obesity in 1976-80 and 1999-2004 Under Alternative Assumptions

\begin{tabular}{|c|c|c|c|c|c|}
\hline Outcome & $\begin{array}{l}\text { 1976-1980: } \\
\text { Actual } \\
\text { (a) }\end{array}$ & $\begin{array}{l}\text { 1976-1980: } \\
\text { at 1999-2004 } \\
\text { Characteristics } \\
\text { (b) }\end{array}$ & $\begin{array}{l}\text { 2001: } \\
\text { Projected at } \\
\text { Median BMI } \\
\text { Growth } \\
\text { (c) }\end{array}$ & $\begin{array}{l}\text { 1999-2004: } \\
\text { Actual } \\
\text { (d) }\end{array}$ & $\begin{array}{c}\text { Increase From } \\
\text { Concentrated } \\
\text { Weight Gains } \\
\text { (e) }\end{array}$ \\
\hline \multicolumn{6}{|c|}{ Males } \\
\hline $\begin{array}{l}\text { Median BMI } \\
\text { Overweight } \\
\text { Obese } \\
\text { Obese: Class } 2 \\
\text { Obese: Class } 3 \\
\text { Obese: Class } 4\end{array}$ & $\begin{array}{c}25.1 \\
51.1 \% \\
12.1 \% \\
2.30 \% \\
0.40 \% \\
0.06 \%\end{array}$ & $\begin{array}{c}25.1 \\
51.4 \% \\
11.3 \% \\
2.17 \% \\
0.47 \% \\
0.21 \%\end{array}$ & $\begin{array}{c}27.1 \\
72.5 \% \\
22.4 \% \\
4.45 \% \\
0.67 \% \\
0.13 \%\end{array}$ & \begin{tabular}{c|}
27.3 \\
$69.1 \%$ \\
$28.7 \%$ \\
$9.61 \%$ \\
$3.34 \%$ \\
$1.23 \%$
\end{tabular} & $\begin{array}{c}9.8 \% \\
-20.8 \% \\
42.7 \% \\
72.5 \% \\
88.1 \% \\
80.5 \%\end{array}$ \\
\hline \multicolumn{6}{|c|}{ Females } \\
\hline $\begin{array}{l}\text { Median BMI } \\
\text { Overweight } \\
\text { Obese } \\
\text { Obese: Class } 2 \\
\text { Obese: Class } 3 \\
\text { Obese: Class } 4\end{array}$ & $\begin{array}{c}23.9 \\
41.2 \% \\
16.7 \% \\
6.35 \% \\
2.13 \% \\
0.75 \%\end{array}$ & $\begin{array}{c}24.2 \\
43.2 \% \\
16.8 \% \\
6.38 \% \\
1.97 \% \\
0.78 \%\end{array}$ & $\begin{array}{c}26.3 \\
62.2 \% \\
26.1 \% \\
10.2 \% \\
3.57 \% \\
1.26 \%\end{array}$ & $\begin{array}{c}26.9 \\
62.0 \% \\
34.1 \% \\
16.1 \% \\
6.91 \% \\
2.88 \%\end{array}$ & $\begin{array}{c}9.5 \% \\
-10.7 \% \\
45.6 \% \\
60.2 \% \\
73.1 \% \\
74.4 \%\end{array}$ \\
\hline \multicolumn{6}{|c|}{ Males \& Females } \\
\hline $\begin{array}{l}\text { Median BMI } \\
\text { Overweight } \\
\text { Obese } \\
\text { Obese: Class } 2 \\
\text { Obese: Class } 3 \\
\text { Obese: Class } 4\end{array}$ & $\begin{array}{c}24.6 \\
45.9 \% \\
14.5 \% \\
4.42 \% \\
1.30 \% \\
0.42 \%\end{array}$ & $\begin{array}{c}24.7 \\
47.2 \% \\
14.1 \% \\
4.33 \% \\
1.24 \% \\
0.51 \%\end{array}$ & $\begin{array}{c}26.7 \\
67.1 \% \\
24.3 \% \\
7.47 \% \\
2.19 \% \\
0.72 \%\end{array}$ & $\begin{array}{c}27.1 \\
65.5 \% \\
31.5 \% \\
13.0 \% \\
5.17 \% \\
2.07 \%\end{array}$ & $\begin{array}{c}11.5 \% \\
-15.1 \% \\
44.4 \% \\
65.4 \% \\
78.7 \% \\
76.5 \%\end{array}$ \\
\hline
\end{tabular}

Note: Projections are based on time trends for the period covered by NHANES 2, 3 and 99 and are obtained from gender-specific estimates that control for race/ethnicity and age. Those projected at "median BMI growth" assumed the same trend increase in BMI for all persons as for the median individual of the same gender. Those "projected for 1976-1980 at 1999-2004 characteristics" allow for variations across the distribution, using the methods described in the text, and are evaluated with the time trend set to the year 1978. "Increases from concentrated weight gains" are calculated as the proportion of the total change (column ( $d$ - column a) not explained by changes in population characteristics (column $b$ - column a) or increases projected at median BMI growth (column c - column a). 
Table 5. BMI and Obesity in 2020 Under Alternative Assumptions

\begin{tabular}{|c|c|c|c|c|}
\hline Outcome & $\begin{array}{l}\text { 1999-2004: } \\
\text { Actual } \\
\text { (a) }\end{array}$ & $\begin{array}{l}\text { 2020: } \\
\text { Projected at } \\
\text { Median BMI } \\
\text { Growth } \\
\text { (b) }\end{array}$ & $\begin{array}{l}\text { 2020: Projected at } \\
\text { Distribution- } \\
\text { Specific BMI } \\
\text { Growth } \\
\text { (c) }\end{array}$ & $\begin{array}{c}\text { Increase From } \\
\text { Concentrated } \\
\text { Weight Gains } \\
\text { (d) }\end{array}$ \\
\hline \multicolumn{5}{|c|}{ Males } \\
\hline $\begin{array}{l}\text { Median BMI } \\
\text { Overweight } \\
\text { Obese } \\
\text { Obese: Class } 2 \\
\text { Obese: Class } 3 \\
\text { Obese: Class } 4\end{array}$ & $\begin{array}{c}27.3 \\
69.1 \% \\
28.7 \% \\
9.61 \% \\
3.34 \% \\
1.23 \%\end{array}$ & $\begin{array}{c}28.9 \\
81.2 \% \\
40.6 \% \\
13.8 \% \\
4.62 \% \\
1.67 \%\end{array}$ & $\begin{array}{c}28.7 \\
77.6 \% \\
40.2 \% \\
16.4 \% \\
6.27 \% \\
3.10 \%\end{array}$ & $\begin{array}{c}-15.0 \% \\
-42.6 \% \\
-3.3 \% \\
37.8 \% \\
56.4 \% \\
75.9 \%\end{array}$ \\
\hline \multicolumn{5}{|c|}{ Females } \\
\hline $\begin{array}{l}\text { Median BMI } \\
\text { Overweight } \\
\text { Obese } \\
\text { Obese: Class } 2 \\
\text { Obese: Class } 3 \\
\text { Obese: Class } 4\end{array}$ & $\begin{array}{c}26.9 \\
62.0 \% \\
34.1 \% \\
16.1 \% \\
6.91 \% \\
2.88 \%\end{array}$ & $\begin{array}{c}28.8 \\
74.5 \% \\
43.4 \% \\
22.0 \% \\
9.99 \% \\
3.92 \%\end{array}$ & $\begin{array}{c}28.6 \\
71.1 \% \\
43.3 \% \\
25.3 \% \\
12.8 \% \\
5.57 \%\end{array}$ & $\begin{array}{c}-14.6 \% \\
-36.6 \% \\
-1.5 \% \\
36.1 \% \\
47.2 \% \\
61.2 \%\end{array}$ \\
\hline \multicolumn{5}{|c|}{ Males \& Females } \\
\hline $\begin{array}{l}\text { Median BMI } \\
\text { Overweight } \\
\text { Obese } \\
\text { Obese: Class } 2 \\
\text { Obese: Class } 3 \\
\text { Obese: Class } 4\end{array}$ & $\begin{array}{c}27.1 \\
65.5 \% \\
31.5 \% \\
13.0 \% \\
5.17 \% \\
2.07 \%\end{array}$ & $\begin{array}{c}28.9 \\
77.7 \% \\
42.1 \% \\
18.0 \% \\
7.38 \% \\
2.82 \%\end{array}$ & $\begin{array}{c}28.7 \\
74.3 \% \\
41.8 \% \\
21.0 \% \\
9.60 \% \\
4.37 \% \\
\end{array}$ & $\begin{array}{l}-10.3 \% \\
-39.4 \% \\
-2.4 \% \\
36.8 \% \\
50.2 \% \\
67.1 \%\end{array}$ \\
\hline
\end{tabular}

Note: Projections are based on time trends for the period covered by NHANES 2, 3 and 99 and are obtained from gender-specific estimates that control for race/ethnicity and age. Those projected at "median BMI growth" assume the same trend increase in BMI for all persons as for the median individual of the same gender. Those projected at "distribution-specific BMI growth" allow for variations across the distribution, using the methods described in the text. "Increases from concentrated weight gains" are calculated as the proportion of the total change (column c - column a) not explained by increases projected at median BMI growth (column $\mathrm{b}$ - column $\mathrm{a}$ ). 
Table A.1. Projected Future Prevalence of Excess Weight, Based on 1999-2004 Population and Using Shorter Time Trends

\begin{tabular}{|c|c|c|c|c|}
\hline \multirow{2}{*}{ Outcome } & \multirow{2}{*}{$\begin{array}{c}\text { 1999-2004 } \\
\text { (Actual) }\end{array}$} & \multicolumn{3}{|c|}{ Projected: } \\
\hline & & 2001 & 2010 & 2010 \\
\hline \multicolumn{5}{|c|}{ Males } \\
\hline Median BMI & 27.3 & $\begin{array}{c}27.2 \\
{[26.5-27.8]}\end{array}$ & $\begin{array}{c}28.2 \\
{[27.4-29.1]}\end{array}$ & $\begin{array}{c}29.4 \\
{[28.3-30.5]}\end{array}$ \\
\hline Overweight & $69.1 \%$ & $\begin{array}{c}69.6 \% \\
{[64.2-75.0]}\end{array}$ & $\begin{array}{c}75.1 \% \\
{[69.7-79.9]}\end{array}$ & $\begin{array}{c}78.9 \% \\
{[73.9-84.9]}\end{array}$ \\
\hline Obese & $38.7 \%$ & $\begin{array}{c}27.9 \% \\
{[23.9-32.0]}\end{array}$ & $\begin{array}{c}36.2 \% \\
{[29.0-43.2]}\end{array}$ & $\begin{array}{c}45.1 \% \\
{[38.4-55.1]}\end{array}$ \\
\hline Obese: Class 2 & $9.61 \%$ & $\begin{array}{c}9.25 \% \\
{[5.57-12.0]}\end{array}$ & $\begin{array}{c}13.9 \% \\
{[9.87-18.2]}\end{array}$ & $\begin{array}{c}19.2 \% \\
{[13.8-25.3]}\end{array}$ \\
\hline Obese: Class 3 & $3.34 \%$ & $\begin{array}{c}3.23 \% \\
{[0.42-5.10]}\end{array}$ & $\begin{array}{c}4.99 \% \\
{[2.39-7.22]}\end{array}$ & $\begin{array}{c}7.88 \% \\
{[4.12-11.5]}\end{array}$ \\
\hline Obese: Class 4 & $1.23 \%$ & $\begin{array}{c}1.24 \% \\
{[0.23-2.21]}\end{array}$ & $\begin{array}{c}2.01 \% \\
{[0.20-3.93]}\end{array}$ & $\begin{array}{c}3.34 \% \\
{[0.19-5.78]}\end{array}$ \\
\hline \multicolumn{5}{|c|}{ Females } \\
\hline Median BMI & 26.9 & $\begin{array}{c}26.8 \\
{[26.1-27.5]}\end{array}$ & $\begin{array}{c}28.1 \\
{[27.2-29.0]}\end{array}$ & $\begin{array}{c}29.6 \\
{[28.4-30.8]}\end{array}$ \\
\hline Overweight & $62.0 \%$ & $\begin{array}{c}62.6 \% \\
{[58.1-67.0]}\end{array}$ & $\begin{array}{c}68.2 \% \\
{[63.3-73.8]}\end{array}$ & $\begin{array}{c}74.1 \% \\
{[68.0-80.0]}\end{array}$ \\
\hline Obese & $34.1 \%$ & $\begin{array}{c}33.4 \% \\
{[27.9-37.8]}\end{array}$ & $\begin{array}{c}40.8 \% \\
{[35.7-44.8]}\end{array}$ & $\begin{array}{c}48.6 \% \\
{[41.7-52.5]}\end{array}$ \\
\hline Obese: Class 2 & $16.1 \%$ & $\begin{array}{c}15.1 \% \\
{[11.7-17.8]}\end{array}$ & $\begin{array}{c}20.8 \% \\
{[15.0-26.8]}\end{array}$ & $\begin{array}{c}29.3 \% \\
{[21.0-35.8]}\end{array}$ \\
\hline Obese: Class 3 & $6.91 \%$ & $\begin{array}{c}6.53 \% \\
{[4.46-9.07]}\end{array}$ & $\begin{array}{c}9.66 \% \\
{[6.15-13.7]}\end{array}$ & $\begin{array}{c}13.8 \% \\
{[8.61-17.7]}\end{array}$ \\
\hline Obese: Class 4 & $2.88 \%$ & $\begin{array}{c}2.72 \% \\
{[0.28-3.89]} \\
\end{array}$ & $\begin{array}{c}4.14 \% \\
{[0.27-6.58]}\end{array}$ & $\begin{array}{c}6.37 \% \\
{[3.01-9.87]}\end{array}$ \\
\hline \multicolumn{5}{|c|}{ Males and Females } \\
\hline Median BMI & 27.1 & $\begin{array}{c}27.0 \\
{[26.6-27.5]}\end{array}$ & $\begin{array}{c}28.2 \\
{[27.6-28.8]}\end{array}$ & $\begin{array}{c}29.6 \\
{[28.8-30.3]}\end{array}$ \\
\hline Overweight & $65.5 \%$ & $\begin{array}{c}66.0 \% \\
{[61.1-70.9]}\end{array}$ & $\begin{array}{c}71.5 \% \\
{[66.4-76.8]}\end{array}$ & $\begin{array}{c}76.4 \% \\
{[70.9-82.4]}\end{array}$ \\
\hline Obese & $31.5 \%$ & $\begin{array}{c}30.8 \% \\
{[25.9-35.0]}\end{array}$ & $\begin{array}{c}38.6 \% \\
{[32.5-44.0]}\end{array}$ & $\begin{array}{c}46.9 \% \\
{[40.1-53.8]}\end{array}$ \\
\hline Obese: Class 2 & $13.0 \%$ & $\begin{array}{c}12.3 \% \\
{[8.72-15.0]}\end{array}$ & $\begin{array}{c}17.4 \% \\
{[12.5-22.6]}\end{array}$ & $\begin{array}{c}24.4 \% \\
{[17.5-30.7]}\end{array}$ \\
\hline Obese: Class 3 & $5.17 \%$ & $\begin{array}{c}4.92 \% \\
{[2.49-7.14]}\end{array}$ & $\begin{array}{c}7.39 \% \\
{[4.32-10.6]}\end{array}$ & $\begin{array}{c}10.9 \% \\
{[6.43-14.7]}\end{array}$ \\
\hline Obese: Class 4 & $2.07 \%$ & $\begin{array}{c}2.00 \% \\
{[0.25-3.07]}\end{array}$ & $\begin{array}{c}3.10 \% \\
{[0.24-5.30]}\end{array}$ & $\begin{array}{c}4.89 \% \\
{[1.64-7.88]}\end{array}$ \\
\hline
\end{tabular}


Note: Predicted prevalence is calculated using the same methods as in Table 4, except that projections are based on time trends for the period covered by the NHANES 4 and 99 surveys only. 


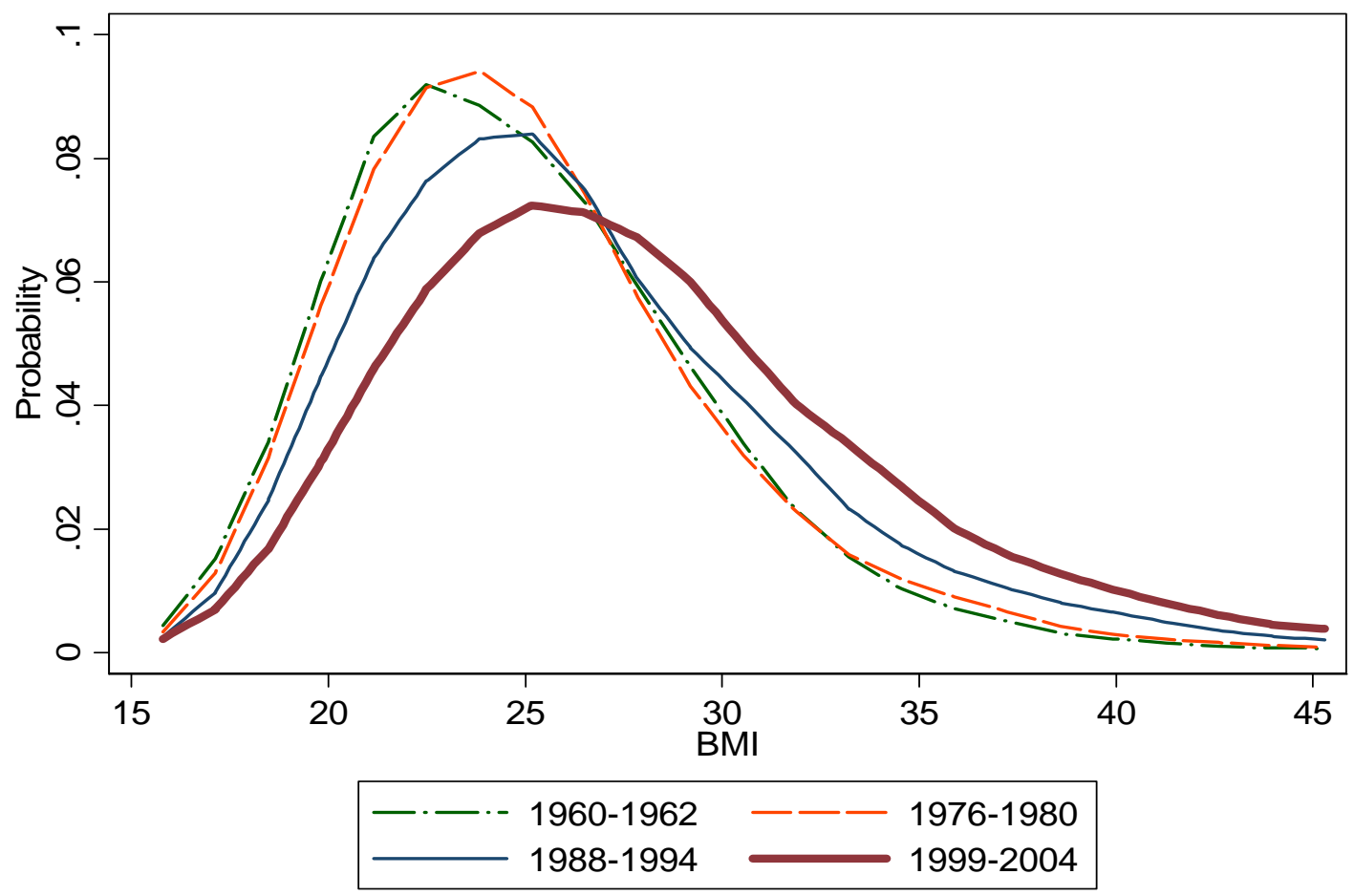

Figure 1. Trends in the Body Mass Index Distribution of 20-74 Year Olds. Data are weighted so as to be nationally representative. 

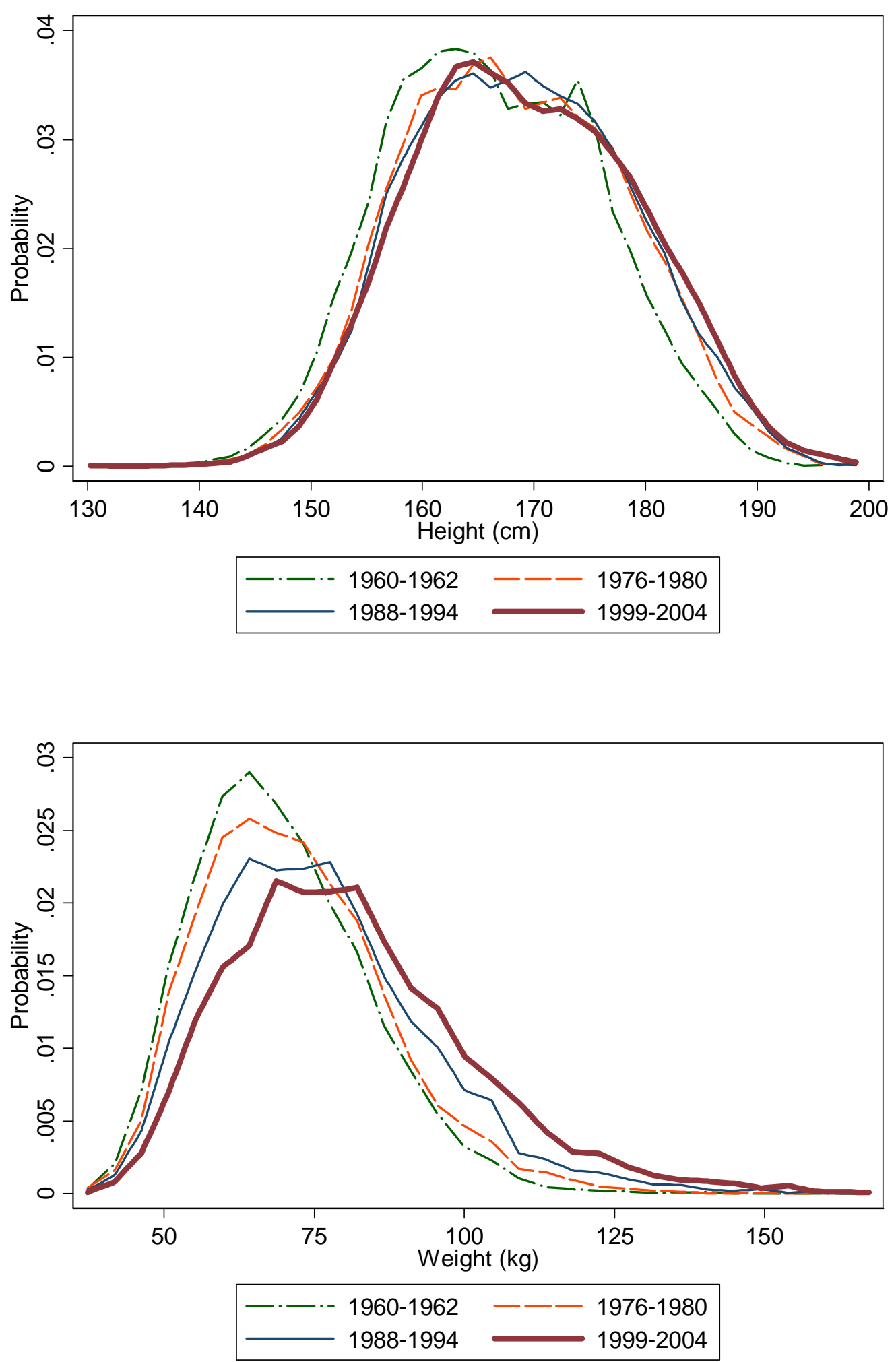

Figure 2. Trends in the Height and Weight of 20-74 Year Olds. Data are weighted so as to be nationally representative. 